\title{
Crowdsourcing Natural Products Discovery to Access Uncharted Dimensions of Fungal Metabolite Diversity
}

\author{
Dr. Lin $\mathrm{Du}^{[+]}$, \\ Department of Chemistry and Biochemistry, Stephenson Life Sciences Research Center, \\ University of Oklahoma, 101 Stephenson Parkway Norman, OK 73019-5251 (USA). Natural \\ Products Discovery Group and Institute for Natural Products Applications and Research \\ Technologies, University of Oklahoma (USA)
}

Andrew J. Robles ${ }^{[+]}$, Department of Pharmacology, University of Texas Health Science Center at San Antonio, 7703 Floyd Curl Drive, San Antonio, TX 78229 (USA)

\begin{abstract}
Jarrod B. King,
Department of Chemistry and Biochemistry, Stephenson Life Sciences Research Center, University of Oklahoma, 101 Stephenson Parkway Norman, OK 73019-5251 (USA). Natural Products Discovery Group and Institute for Natural Products Applications and Research Technologies, University of Oklahoma (USA)
\end{abstract}

\section{Dr. Douglas R. Powell, \\ Department of Chemistry and Biochemistry, Stephenson Life Sciences Research Center, University of Oklahoma, 101 Stephenson Parkway Norman, OK 73019-5251 (USA)}

\section{Prof. Dr. Andrew N. Miller,}

Ilinois Natural History Survey, University of Illinois, 1816 South Oak Street, Champaign, IL 61820-6970 (USA)

\section{Prof. Dr. Susan L. Mooberry, and}

Department of Pharmacology, University of Texas Health Science Center at San Antonio, 7703 Floyd Curl Drive, San Antonio, TX 78229 (USA). Cancer Therapy \& Research Center and Department of Medicine, University of Texas Health Science Center at San Antonio (USA)

\section{Prof. Dr. Robert H. Cichewicz}

Department of Chemistry and Biochemistry, Stephenson Life Sciences Research Center, University of Oklahoma, 101 Stephenson Parkway Norman, OK 73019-5251 (USA). Natural

\footnotetext{
** Research reported in this publication was supported by the National Institute of General Medical Sciences of the National Institutes of Health RO1GM092219 (RHC), the President's Council Excellence Award (SLM), and with support from the CTRC P30 Cancer Center Support Grant (CA054174) and the Flow Cytometry Shared Resource (SLM). The X-ray diffractometer was purchased through a grant from the NSF (CHE-0130835). The LC-MS instrument used for this project was provided in part by a Challenge Grant from the Office of the Vice President for Research, University of Oklahoma, Norman Campus and an award through the Shimadzu Equipment Grant Program (RHC). We gratefully acknowledge Ms. A. Reyor for supplying the soil sample used in this study.

Correspondence to: Susan L. Mooberry, mooberry@uthscsa . edu; Robert H. Cichewicz, rhcichewicz@ou .edu.

$[+]$ These authors contributed equally to this work.

Supporting information for this article is available on the WWW under http://www.angewandte.org
} 


\section{Products Discovery Group and Institute for Natural Products Applications and Research Technologies, University of Oklahoma (USA)}

Susan L. Mooberry: mooberry@uthscsa.edu; Robert H. Cichewicz: rhcichewicz@ou.edu

\section{Abstract}

A new Tolypocladium sp. was obtained through a crowdsourcing initiative. Triggering the expression of a silent biosynthetic pathway in this fungus was achieved through chemical epigenetics, culture medium manipulation, and co-culture to yield the unique polyketideshikimate-NRPS-hybrid compound, maximiscin, which demonstrated in vivo antitumor activity.

\section{Keywords}

epigenetics; shikimate-PKS-NRPS; crowdsourcing; Pgp; xenograft cancer

Fungi are a remarkable source of novel secondary metabolites, many of which have been developed for clinical applications. ${ }^{[1]}$ Despite increasing interest in fungal secondary metabolites, ${ }^{[2]}$ it is estimated that less than $7 \%$ of the $>1.5$ million species of fungi have been subjected to an investigation of their bioactive constituents. ${ }^{[3]}$ It is reasonable to postulate that a significant number of compounds with potential therapeutic relevance await discovery from the largely untapped majority of fungal species.

During the last four years, our research group has prepared a collection of several thousand fungal isolates originating from three environmentally disparate regions: Alaska (arctic/subarctic), Hawaii (tropical), and Oklahoma (subtropical/semi-arid). Our collection efforts have been supplemented through a crowdsourcing program in which "citizen scientists" are invited to submit soil samples from their personal properties. ${ }^{[4]}$ Crowdsourcing is emerging as an important tool for engaging the public in the scientific process thereby enabling research teams to analyze, as well as access critical information and/or specimens that would otherwise remain inaccessible to scientific investigation. Crowdsourcing approaches have been used to address a wide variety of scientific questions/problems including the distribution pattern of volcanic ash from Grímsvötn, ${ }^{[5 a]}$ the analysis of historic weather data, ${ }^{[5 b]}$ classifying newly discovered galaxies, ${ }^{[5 c]}$ mapping emergency medical equipment, ${ }^{[5 \mathrm{~d}]}$ and other applications. ${ }^{[5 \mathrm{e}]}$

Extracts from a majority of the fungal isolates incorporated into our collection have been screened by LC-MS and/or subjected to a panel of bioassays (cancer cell cytotoxicity, antibacterial, antifungal, and inhibition of fungal biofilm formation) resulting in the isolation of several intriguing compounds. ${ }^{[6]}$ Recently, we identified a Tolypocladium sp. isolate (based on ITS sequence data and morphological features) through our group's crowdsourcing initiative that was highly responsive to a range of culture manipulation strategies (Figure 1). Initially, an extract prepared from the fungus grown in potato dextrose broth (PDB) (10 g/L dried mashed potato, $5 \mathrm{~g} / \mathrm{L}$ glucose, $\left.2 \mathrm{~g} / \mathrm{L} \mathrm{NaNO}_{3}\right)$ showed the presence of two 15-residue peptides, efrapeptins F (5) and G (6) (Figures 1A and 1E). When treated with the epigenetic modifier 5-azacytidine (DNA methylation inhibitor, $100 \mu \mathrm{M}$ ) (Figures $1 \mathrm{~B}$ and $1 \mathrm{~B}^{\prime}$ ), co-cultured with Pseudomonas fulva (Figures $1 \mathrm{C}$ and $1 \mathrm{C}^{\prime}$ ), or grown 
in PDB medium without $\mathrm{NaNO}_{3}$ (Figures $1 \mathrm{D}$ and $1 \mathrm{D}^{\prime}$ ), the production of peptides 5 and $\mathbf{6}$ was suppressed, while a new polyketide-shikimate-NRPS-hybrid metabolite, maximiscin [(P/M)-1], was obtained. These changes were accompanied by the production of (-)-methyl shikimate (4) ${ }^{[7]}$ and the tetramic acid metabolite, F-14329 (2), ${ }^{[8]}$ which appeared to have biosynthetic origins similar to $(\boldsymbol{P} / \boldsymbol{M})$-1. Furthermore, when the fungus was treated with 5azacytidine in PDB without $\mathrm{NaNO}_{3}$, the biosynthesis of $(\boldsymbol{P} / \boldsymbol{M})$-1 was nearly suppressed, but the production of the polyketide-NRPS metabolite pyridoxitan was observed $[(\boldsymbol{P} / \boldsymbol{M})-\mathbf{3}$, Supporting Information, Figure S3]. ${ }^{[9]}$

In solution, $(\boldsymbol{P} / \boldsymbol{M})-\mathbf{1}$ was detected as a $~ 9: 5$ mixture of two rapidly interconverting atropisomers (Figure 1). The planar structures and relative configurations of moieties A and $\mathrm{B}$ in $(\boldsymbol{P} / \boldsymbol{M})-1$ were established by comprehensive analysis of the HRESIMS and $1 \mathrm{D}\left({ }^{1} \mathrm{H}\right.$ and $\left.{ }^{13} \mathrm{C}\right)$ and 2D NMR $\left({ }^{1} \mathrm{H}_{-}{ }^{1} \mathrm{H}\right.$ COSY,${ }^{1} \mathrm{H}_{-}{ }^{13} \mathrm{C}$ HSQC, ${ }^{1} \mathrm{H}_{-}{ }^{13} \mathrm{C}$ HMBC, and ${ }^{1} \mathrm{H}_{-}{ }^{1} \mathrm{H}$ REOSY $)$ data. Although no ${ }^{1} \mathrm{H}_{-}{ }^{13} \mathrm{C} \mathrm{HMBC}$ correlations were detected linking the two fragments, the downfield shift of C- $6^{\prime}\left(\delta_{\mathrm{C}} 86.5\right)$ relative to the carbasugar analogues (+/-)-pericosines $\mathrm{B}$ and $\mathrm{C}^{[10]}\left(\delta_{\mathrm{C}} 76 \sim 79\right)$ and a ${ }^{1} \mathrm{H}-{ }^{1} \mathrm{H}$ ROESY correlation between $\mathrm{H}-6$ and $\mathrm{H}-6{ }^{\prime}$, provided compelling evidence that the substructures were joined via a $\mathrm{O}=\mathrm{C}-\mathrm{N}-\mathrm{O}-\mathrm{C}$ bridge between moieties A and $\mathrm{B}$. The $\mathrm{O}=\mathrm{C}-\mathrm{N}-\mathrm{O}-\mathrm{C}$ bridge in $(\boldsymbol{P} / \boldsymbol{M})-\mathbf{1}$ is unusual among natural products. In contrast, similar $\mathrm{N}-\mathrm{O}-\mathrm{C}$ bridges have been described from a limited number of natural sources (e.g., the enediyne-antibiotic calicheamicins from Micromonospora echinospora $\left.{ }^{[11]}\right)$.

To further investigate the metabolite's absolute configuration, a methanolic solution of (P/ M)-1 was mixed with $\mathrm{CuSO}_{4}$ and subjected to stirring at room temperature for seven days. ${ }^{[12]}$ Upon purification of the reaction mixture, blue crystals of a $\mathrm{Cu}$ (pyridoxitan) 2 chelate (7) together with a carbasugar product were obtained (Scheme 1). Single crystal Xray diffraction analysis of the blue crystalline material revealed two organometallic complexes, $(\boldsymbol{P}, \boldsymbol{M})-\mathbf{7}$ and $(\boldsymbol{P}, \boldsymbol{P})-\mathbf{7}$, co-located in the crystal lattice, which established the absolute configuration for this portion of the molecule as $7 R, 8 S, 10 R, 12 S$. Our data (Supporting Information, Page S8) for the carbasugar product 8 matched literature values reported for (+)-pericosine C. ${ }^{[10]}$ In light of the relative configuration we had proposed for the carbasugar in $(\boldsymbol{P} / \boldsymbol{M})-\mathbf{1}$, this result implied that the $\mathrm{C}-6^{\prime}$ position underwent epimerization during methanolysis to yield a compound with a $3 S, 4 S, 5 S, 6 S$ configuration (Scheme 1). The $\mathbf{6}^{\prime} \boldsymbol{R}$ configuration of (P/M)-1 was confirmed by comparison of the VCD spectrum (Figure 2) and specific rotation $\left([a]^{20} D-147\right)$ of the metabolite with the theoretical VCD spectra (Figure 2) and specific rotation of $\mathbf{6}^{\prime} \boldsymbol{R}-(\boldsymbol{P} / \boldsymbol{M})-\mathbf{1}\left([\boldsymbol{a}]_{\mathrm{D}}-94\right)$ and $\mathbf{6}^{\prime} S-(\boldsymbol{P} / \boldsymbol{M})-\mathbf{1}\left([\mathrm{a}]_{\mathrm{D}}+151\right)$ generated by quantum chemical calculations (Supporting Information, Tables S3 and S4). (P/M)-1 exhibited strong VCD signals in the range of $1200 \sim 1450 \mathrm{~cm}^{-1}$ that matched well with the calculated VCD spectrum of the $\mathbf{6}^{\prime} \boldsymbol{R}-(\boldsymbol{P} / \boldsymbol{M})-\mathbf{1}$ diastereomer (Figure 2). In contrast to previous VCD studies of stable atropisomers, ${ }^{[13]}$ this application of VCD to an interconverting atropisomeric mixture required special consideration of the conformer populations attributable to both molecules in order to carry out predictive quantum chemical calculations. 
To assign which sets of ${ }^{1} \mathrm{H}$ and ${ }^{13} \mathrm{C}$ NMR spins were attributable to each of the atropisomers, the ${ }^{13} \mathrm{C}$ NMR resonances for $(\boldsymbol{P} / \boldsymbol{M})$-1 were compared to values published for stable analogs, as well as data obtained from $a b$ initio quantum chemical calculations. A well-defined trend was observed for the calculated differences between the ${ }^{13} \mathrm{C}$ NMR shifts of C-2, C-4, C-8, and C-12 for the $P$ and $M$ isomers of $\mathbf{1}$, pyridoxitan (3), ${ }^{[9]}$ and cordypyridones A $[(\boldsymbol{P})-9]$ and B $[(\boldsymbol{M})-9],{ }^{[14]}$ which closely matched their respective published data sets (Supporting Information, Figure S2). Applying this trend, we were able to assign the $P$ and $M$ atropisomers of $(\boldsymbol{P} / \boldsymbol{M}) \mathbf{- 1}$ to their respective NMR data sets (Supporting Informtion, Table S1).

Stable isotope labeling experiments with ${ }^{13} \mathrm{C}$ and ${ }^{15} \mathrm{~N}$ enriched precursors were carried out on $(\boldsymbol{P} / \boldsymbol{M})$-1 using the substrates listed in Table S2 (Supporting Information). Feeding experiments employing $\left[3-{ }^{13} \mathrm{C}\right]-\mathrm{D}$-glucose and $\left[\mathrm{U}_{-}{ }^{13} \mathrm{C}_{6}\right]-\mathrm{D}$-glucose provided evidence that the carbasugar was derived from a shikimate pathway (Scheme 2 and Supporting Informtion, Figure S4). ${ }^{[15]}$ Based on our studies, it is not certain if the stereocenters in the carbasugar are fixed early (route B) or late (route A) during the biosynthetic process (Scheme 2). Further supplementation of the culture medium with $\left[1-{ }^{13} \mathrm{C}\right]$ sodium acetate and $\left[2-{ }^{13} \mathrm{C}\right]$ sodium acetate enabled us to infer the likely polyketide origins of carbon atoms $\mathrm{C}-2$, C-3, and C-7 through C-14 in (P/M)-1 (Scheme 2 and Supporting Informtion, Table S2). Although the biosynthetic pathways of related tetramic acids and 5- phenyl-pyridones have been investigated, ${ }^{[16]}$ the NRPS origins of C-4, C-5, C-6 and N-1 in 5-H-pyridones (e.g., pyridoxitan, $\mathrm{PF} 1140, N$-deoxy-PF1140, and related compounds) had not been unequivocally defined. Considering the related structural features of $(\boldsymbol{P} / \boldsymbol{M})-\mathbf{1}$ and F-14329 (2) ${ }^{[8]}$, we speculated that tyrosine could serve as the preferred or only substrate utilized in the biosynthesis of related $5-\mathrm{H}$-pyridones. To test this, $\left[1-{ }^{13} \mathrm{C}\right]$-L-tyrosine and $\left[{ }^{15} \mathrm{~N}\right]-\mathrm{L}$-tyrosine were added to the fungal culture resulting in isotope incorporation at position C-4 (an enrichment factor of 11.8, Supporting Information, Table S2) and N-1 (Supporting Information, Figure S33) of (P/M)-1, respectively. Moreover, we observed that [U-13 $\mathrm{C}_{6}$ ]-Dglucose feeding led to the contiguous ${ }^{13} \mathrm{C}$-enrichment of C-4, C-5, and C-6 (Supporting Informtion, Table S2) as anticipated for the catabolic/anabolic transformation of glucose to tyrosine (Scheme 2 and Supporting Informtion, Figure S4). These data provided evidence for the direct incorporation of tyrosine into $(\boldsymbol{P} / \boldsymbol{M}) \mathbf{- 1}$, which was then biotransformed by the fungus to remove the phenol moiety. The proposed pathway for the formation of $(\boldsymbol{P} / \boldsymbol{M})-\mathbf{1}$ provides a compelling rationale for how other $N$-hydroxy-pyridone-containing natural products may be generated through a parallel biosynthetic process. In light of the unique mixed biosynthetic origins of $(\boldsymbol{P} / \boldsymbol{M})$ - 1, we have given this metabolite the colloquial name maximiscin, based loosely on a combination of the Latin words maximopere (meaning very or exceedingly) and miscellus (meaning blended).

The antiproliferative and cytotoxic activities of $(\boldsymbol{P} / \boldsymbol{M}) \mathbf{- 1}$ were tested in the NCI-60 in vitro cell panel. Compound $(\boldsymbol{P} / \boldsymbol{M}) \mathbf{- 1}$ exhibited antiproliferative activity against several cell lines, with an average $\mathrm{GI}_{50}$ value of $0.39 \mu \mathrm{M}$ (Supporting Information, Table S6). Closer examination of these data revealed that the UACC-62 melanoma cell line was not only sensitive to $(\boldsymbol{P} / \boldsymbol{M})-\mathbf{1}\left(\mathrm{LC}_{50}=0.93 \mu \mathrm{M}\right)$, but it also exhibited a monophasic dose-response curve (Supporting Informtion, Figure S29A) that was dissimilar to the biphasic dose- 
response curves exhibited by most of the other cell lines. For example, the dose-response curves for $(\boldsymbol{P} / \boldsymbol{M})$-1 against both the MDA-MB-453 and HeLa cell lines were biphasic (Supporting Informtion, Figure S29A), indicating the possibility of two separate mechanisms of action. Although this response pattern was robust and fully reproducible, further studies will be required to elucidate the specific mechanisms of action of $(\boldsymbol{P} / \boldsymbol{M})-\mathbf{1}$ in these different cell lines.

A common mechanism of drug resistance exhibited by cancer cells is expression of Pgp (product of the MDRl gene), which contributes to the efflux of drugs and toxic substrates. ${ }^{[17]}$ To determine if $(\boldsymbol{P} / \boldsymbol{M}) \mathbf{- 1}$ can overcome Pgp-mediated resistance, the compound was evaluated in a SK-OV-3/MDR-1-6/6 ovarian cancer cell line transduced with $\mathrm{Pgp}^{[18]}$ and compared to the untransformed parent SK-OV-3 cell line. The SK-OV-3/ MDR-1-6/6 cell line demonstrated substantial resistance to the antiproliferative effects of PTX (Figure 3). In contrast, (P/M)-1 exhibited equivalent inhibitory activities against both cell lines, suggesting it is not a substrate for Pgp (Figure 3).

Based on the potency and monophasic dose-response pattern of $(\boldsymbol{P} / \boldsymbol{M})-\mathbf{1}$ against the UACC-62 cells, this cell line was chosen for further studies. A clonogenic assay was performed to determine the capacity of $(\boldsymbol{P} / \boldsymbol{M}) \mathbf{- 1}$ to inhibit colony formation and the persistence of its cellular effects in UACC-62 cells. Cells were treated with $(\boldsymbol{P} / \boldsymbol{M})-\mathbf{1}$ for $8 \mathrm{~h}$ after which the compound was removed by washing the cells. Treatment at a concentration of $6 \mu \mathrm{M}$ resulted in a significant decrease in colony formation $(p \leq 0.01)$ compared to vehicle-treated controls (Figure 4). These results indicate that subsequent to drug removal, the biological effects of $(\boldsymbol{P} / \boldsymbol{M}) \mathbf{- 1}$ against UACC-62 cells are moderately persistent.

With these promising results, we proceeded to investigate whether $(\boldsymbol{P} / \boldsymbol{M}) \mathbf{- 1}$ had antitumor activity in vivo by evaluating its activity in a UACC-62 xenograft mouse model. Athymic nude mice bearing UACC-62 xenograft tumors were treated by administering $(\boldsymbol{P} / \boldsymbol{M}) \mathbf{- 1}(5$ $\mathrm{mg} / \mathrm{kg}$ ) daily for $5 \mathrm{~d}$, withholding treatment for $2 \mathrm{~d}$, and providing daily treatment with (P/ $M)-1(5 \mathrm{mg} / \mathrm{kg})$ for an additional $5 \mathrm{~d}$. This dosing schedule provided significant inhibition of tumor growth relative to untreated control mice ( $p=0.027$ ) (Figure 5) without causing substantial weight loss (Supporting Information, Figure S29). It is noteworthy that the UACC-62 cell line forms an aggressive, rapid-growing tumor in vivo, so the experiment was discontinued after $14 \mathrm{~d}$ due to excessive tumor burden in the control mice.

In summary, a new Tolypocladium sp. isolate was obtained through our crowdsourcing initiative. This isolate produced the unique polyketide-shikimate-NRPS-hybrid compound $(\boldsymbol{P} / \boldsymbol{M})$-1 via chemical epigenetic induction, culture medium variation, and bacterial coculture strategies. The results of these studies speak to the multitude of interdependent factors involved in stimulating fungal secondary metabolite biosynthesis. Compound (P/ $\boldsymbol{M})$-1, which possesses an unusual $\mathrm{O}=\mathrm{C}-\mathrm{N}-\mathrm{O}-\mathrm{C}$ bridge, showed in vitro cytotoxic activity against a number of cell types and in vivo antitumor activity in a UACC-62 xenograft cancer model. Moreover, $(\boldsymbol{P} / \boldsymbol{M}) \mathbf{- 1}$ exhibited an ability to circumvent Pgp-mediated drug resistance, which makes this a potentially valuable compound for further investigation. These results also highlight the remarkable opportunities that exist for fostering the meaningful 
involvement of citizen scientists in research programs and how their involvement can substantially enhance scientific investigations.

\section{Supplementary Material}

Refer to Web version on PubMed Central for supplementary material.

\section{References}

1. a) Kartsonis NA, Nielsen J, Douglas CM. Drug Resist Updat. 2003; 6:197-218. [PubMed: 12962685] b) Kardos N, Demain AL. Appl Microbiol Biotechnol. 2011; 92:677-687. [PubMed: 21964640] c) Endo A. Proc Jpn Acad, Ser B. 2010; 86:484-493. [PubMed: 20467214]

2. a) Stadler M, Keller NP. Mycol Res. 2008; 112:127-130. [PubMed: 18319144] b) Wang LW, Zhang YL, Lin FC, Hu YZ, Zhang CL. Mini Rev Med Chem. 2011; 11:1056-1074. [PubMed: 21861806] c) Rateb ME, Ebel R. Nat Prod Rep. 2011; 28:290-344. [PubMed: 21229157]

3. Hawksworth DL. Stud Mycol. 2004:9-17.

4. Natural Product Discovery Group. [accessed May 14, 2013] Home Page http://npdg.ou.edu/ citizenscience

5. a) Grímsvötn. [accessed May 14, 2013] Ash Collection Findings. 2011. Web Page http:// www.bgs.ac.uk/discoveringGeology/hazards/volcanoes/grimsvotn2011.htmlb) Gura T. Nature. 2013; 496:259-261. [PubMed: 23586092] c) Lintott C, Schawinski K, Bamford S, Slosar A, Land K, Thomas D, Edmondson E, Masters K, Nichol RC, Raddick MJ, Szalay A, Andreescu D, Murray P, Vandenberg J. Mon Not R Astron Soc. 2011; 410:166-178.d) Merchant RM, Asch DA, Hershey JC, Griffis HM, Hill S, Saynisch O, Leung AC, Asch JM, Lozada K, Nadkarni LD, Kilaru A, Branas CC, Stone EM, Starr L, Shofer F, Nichol G, Becker LB. Circ Cardiovasc Qual Outcomes. 2013; 6:229-236. [PubMed: 23481522] e) The CornellLab of Ornithology-Citizen Science Central. [accessed May 14, 2013] Web Page. http://www.birds.cornell.edu/citscitoolkit

6. a) Wang XR, You JL, King JB, Powell DR, Cichewicz RH. J Nat Prod. 2012; 75:707-715. [PubMed: 22400916] b) Du L, King JB, Morrow BH, Shen JK, Miller AN, Cichewicz RH. J Nat Prod. 2012; 75:1819-1823. [PubMed: 23046341]

7. Armesto N, Fernandez S, Ferrero M, Gotor V. Tetrahedron. 2006; 62:5401-5410.

8. Takashi, N.; Mutsuo, N.; Hidetake, K.; Masaaki, T.; Isshin, T. Jpn Kokai Tokkyo Koho. JP 2007153840 A 20070621. 2007.

9. Teshima Y, Shin-ya K, Shimazu A, Furihata K, Chul HS, Furihata K, Hayakawa Y, Nagai K, Seto H. J Antibiot. 1991; 44:685-687. [PubMed: 2071495]

10. a) Yamada T, Iritani M, Ohishi H, Tanaka K, Minoura K, Doi M, Numata A. Org Biomol Chem. 2007; 5:3979-3986. [PubMed: 18043803] b) Reddy YS, Kadigachalam P, Basak RK, Pal APJ, Vankar YD. Tetrahedron Lett. 2012; 53:132-136.c) Usami Y, Ohsugi M, Mizuki K, Ichikawa H, Arimoto M. Org lett. 2009; 11:2699-2701. [PubMed: 19514797] d) Usami Y, Ueda Y. SynthesisStuttgart. 2007:3219-3225.

11. Lee MD, Manning JK, Williams DR, Kuck NA, Testa RT, Borders DB. J Antibiot. 1989; 42:10701087. [PubMed: 2753814]

12. Momiyama N, Yamamoto H. J Am Chem Soc. 2003; 125:6038-6039. [PubMed: 12785817]

13. a) Cichewicz RH, Clifford LJ, Lassen PR, Cao X, Freedman TB, Nafie LA, Deschamps JD, Kenyon VA, Flanary JR, Holman TR, Crews P. Bioorg Med Chem. 2005; 13:5600-5612. [PubMed: 16039133] b) Freedman TB, Cao X, Nafie LA, Kalbermatter M, Linden A, Ripper AJ. Helv Chim Acta. 2005; 88:2302-2314.

14. Isaka M, Tanticharoen M, Kongsaeree P, Thebtaranonth Y. J Org Chem. 2001; 66:4803-4808. [PubMed: 11442408]

15. Bentley R. Crit Rev Biochem Mol. 1990; 25:307-384.

16. Boettger D, Hertweck C. Chem Bio Chem. 2013; 14:28-42.

17. Nobili S, Landini I, Mazzei T, Mini E. Med Res Rev. 2012; 32:1220-1262. [PubMed: 21374643]

18. Sadava D, Coleman A, Kane SE. J Liposome Res. 2002; 12:301-309. [PubMed: 12519627] 
19. Boyd, MR.; Paull, KD.; Rubinstein, LR. Cytotoxic Anticancer Drugs: Models and Concepts for Drug Discovery and Development. Valeriote, FA.; Corbett, T.; Baker, L., editors. Kluwer Academic Publishers; 1992. p. 1134 

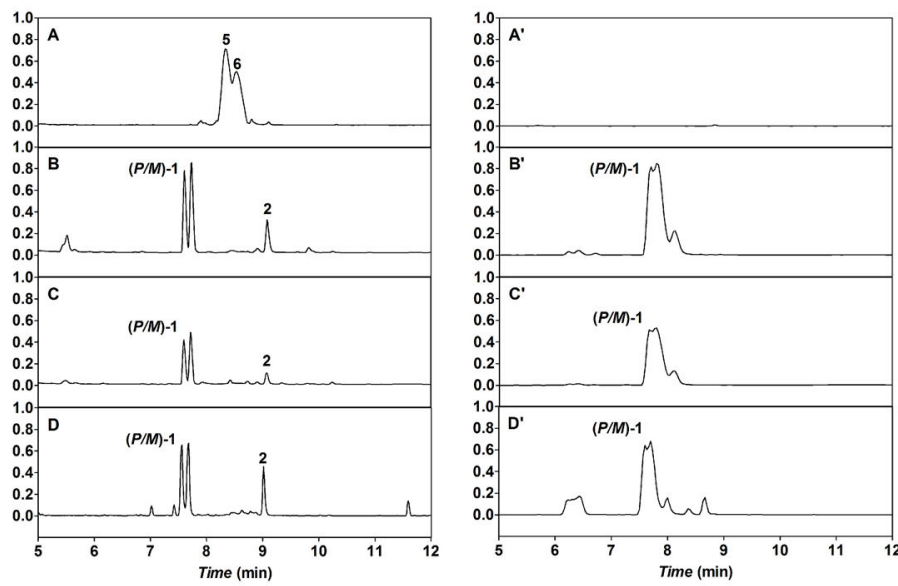

E

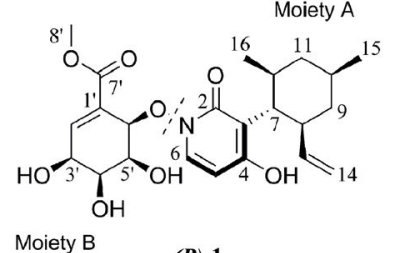

(P)-1

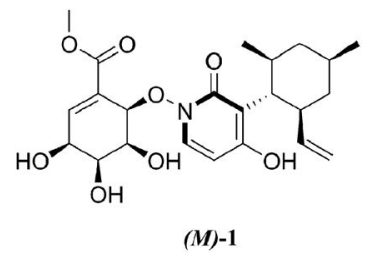<smiles>C/C=C/CC(C)CC(C)C(O)=C1C(=O)NC([C@H](O)c2ccc(O)cc2)C1=O</smiles><smiles>COC(=O)C1=CC(O)C(O)C(O)C1</smiles>

2

4<smiles>C=CC1CC(C)CC(C)C1c1c(O)ccn(O)c1=O</smiles><smiles>C=C[C@H]1CC(C)CC(C)C1c1c(O)ccn(O)c1=O</smiles>

(P) -3

(M) -3

Efrapeptin F (5): Ac-Pip-Aib-Pip-Aib-Aib-Leu-ßAla-Gly-Aib-Aib-Pip-Aib-Ala-Leu-Iva-X Efrapeptin G (6): Ac-Pip-Aib-Pip-Iva-Aib-Leu-BAla-Gly-Aib-Aib-Pip-Aib-Ala-Leu-Iva-X<smiles>[Y][Y]C(C)NC1Cc2n3[n+](c4[n+]2CCC4)CCC3C(C)C1</smiles>

Figure 1.

LC-MS profiling [PDA traces at 200 600 nm (A D) and (+) ESI-MS traces at $m / z 464$ (A $\left.{ }^{\prime} \sim \mathrm{D}^{\prime}\right)$ ] of selected secondary metabolites produced by the Tolypocladium sp. isolate and structures of the noted compounds (E). The fungus was cultured under the following conditions: $\mathrm{PDB}$ with $\mathrm{NaNO}_{3}$ (A and $\mathrm{A}^{\prime}$ ), $\mathrm{PDB}$ with $\mathrm{NaNO}_{3}$ and 5-azacytidine (B and $\mathrm{B}^{\prime}$ ), $\mathrm{PDB}\left(\mathrm{C}\right.$ and $\left.\mathrm{C}^{\prime}\right)$, co-culture with Pseudomonas fulva in $\mathrm{PDB}$ with $\mathrm{NaNO}_{3}\left(\mathrm{D}\right.$ and $\left.\mathrm{D}^{\prime}\right)$. 


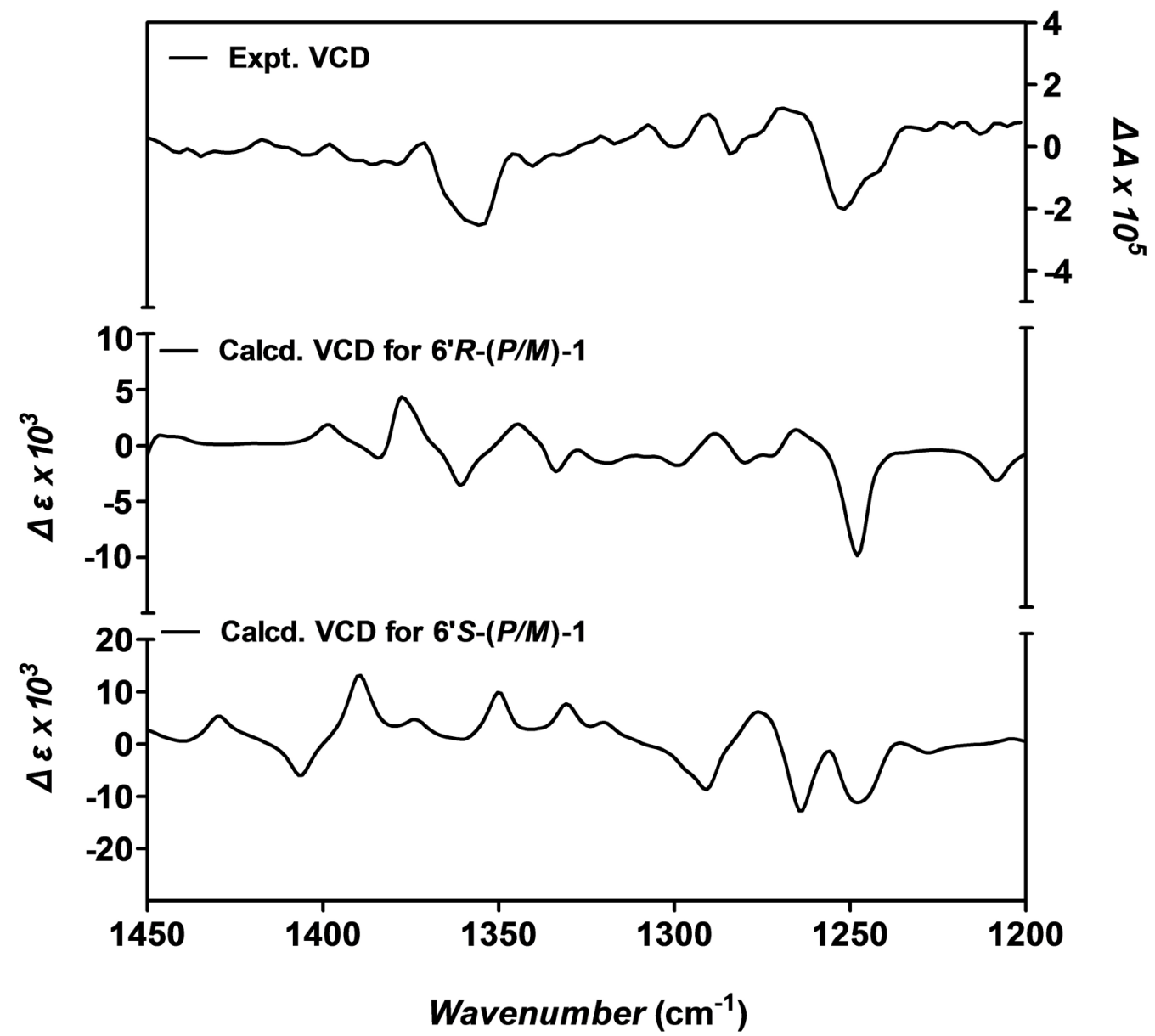

Figure 2.

Comparison of the experimental VCD spectrum of $(\boldsymbol{P} / \boldsymbol{M})-\mathbf{1}\left(\mathrm{DMSO}-\boldsymbol{d}_{6}\right)$ with the calculated VCD spectra of $\mathbf{6}^{\prime} \boldsymbol{R}-(\boldsymbol{P} / \boldsymbol{M})-\mathbf{1}$ and $\mathbf{6}^{\prime} \boldsymbol{S}-(\boldsymbol{P} / \boldsymbol{M})-\mathbf{1}$. 


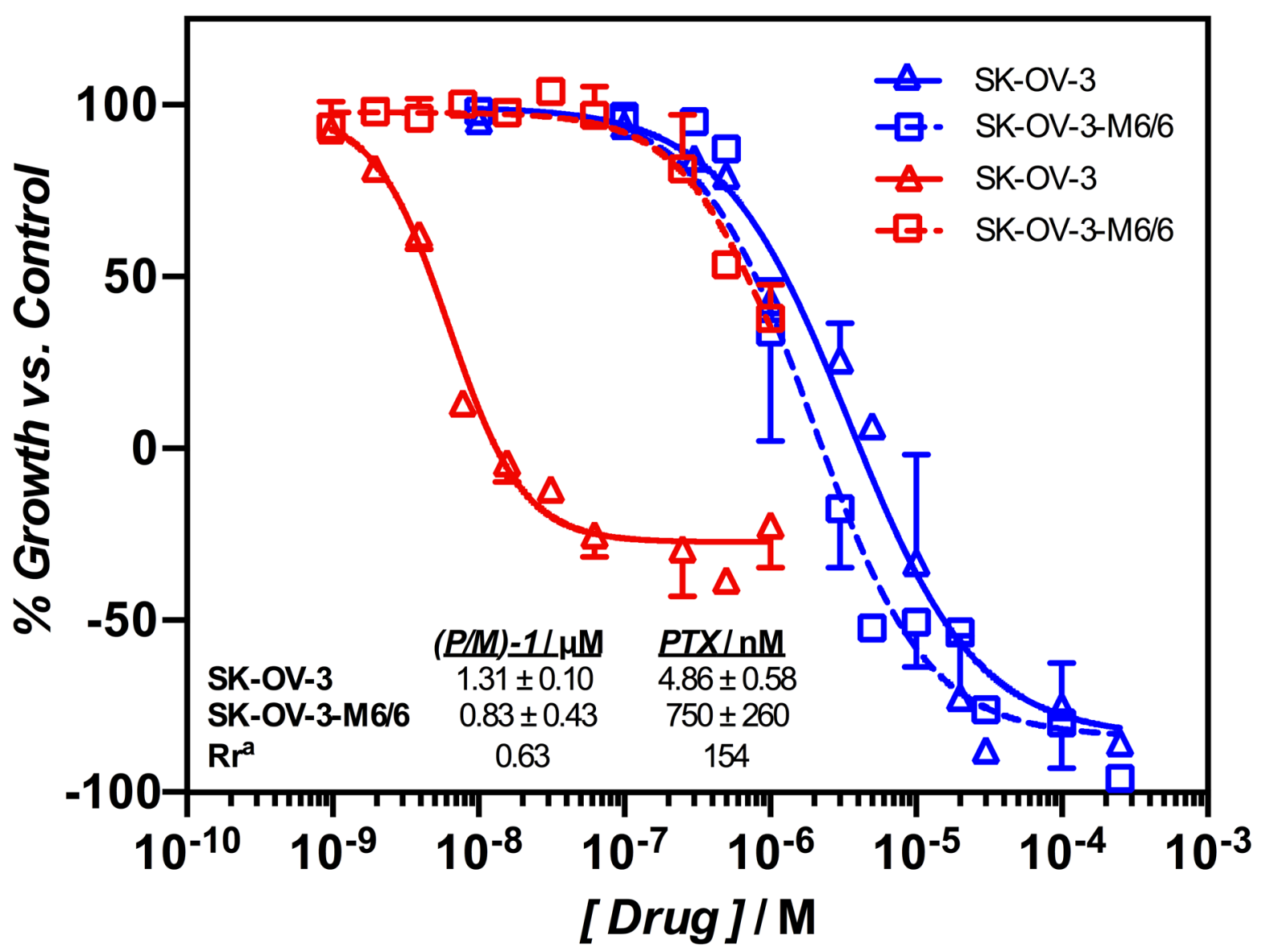

Figure 3.

Dose-response curves for growth inhibition of SK-OV-3 and SK-OV-3-M6/6 cells after $48 \mathrm{~h}$ of treatment with $(\boldsymbol{P} / \boldsymbol{M})-\mathbf{1}$ or PTX (paclitaxel). Data points represent the mean \pm SE for three independent experiments, performed in triplicate. Error bars, when not visible, are within the boundaries of the data points. $\mathrm{GI}_{50}$ values represent the mean \pm SD for three independent experiments, performed in triplicate. Percent growth was calculated as previously described. ${ }^{[19]}$ a $\mathrm{Rr}$ (Relative resistance) values were calculated as the $\mathrm{GI}_{50}$ in SK$\mathrm{OV}-3-\mathrm{M} 6 / 6$ cells $\div \mathrm{GI}_{50}$ in SK-OV-3 cells. 
A.

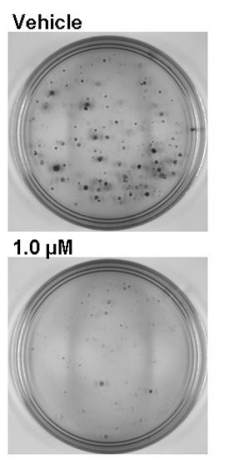

B.

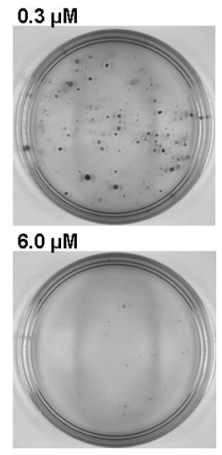

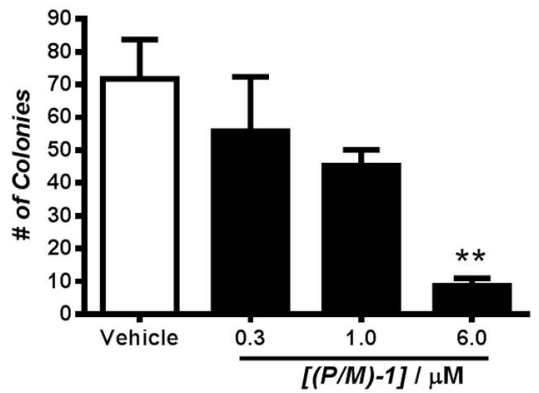

Figure 4.

Clonogenic assay results for UACC-62 cells after $8 \mathrm{~h}$ of exposure to $(\boldsymbol{P} / \boldsymbol{M})-\mathbf{1}$ at the indicated concentrations. (A) Representative images of UACC-62 cell colonies after 14 days of growth and crystal violet staining. (B) Quantification of mean colony numbers for three independent experiments, performed in duplicate or triplicate. Error bars represent SD. **P $<0.01$ compared to vehicle; one-way ANOVA with Dunnett's post-hoc test. 
A.

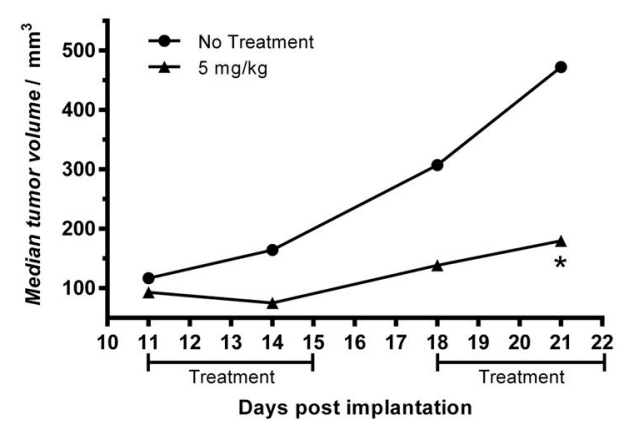

B.

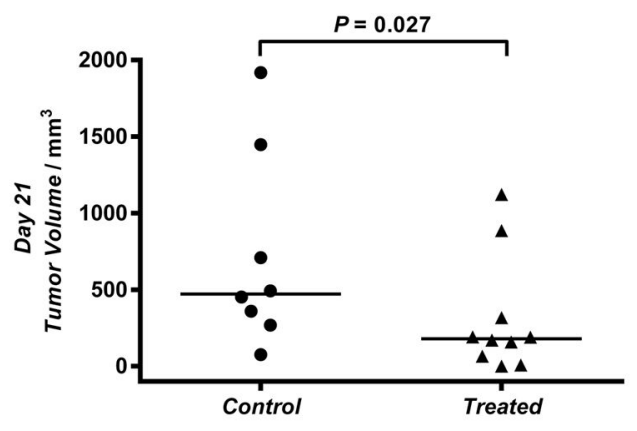

Figure 5.

Inhibition of UACC-62 xenograft tumor growth in nude mice by $(\boldsymbol{P} / \boldsymbol{M})$-1. (A) Growth curves showing the median tumor volume ( $n=8-10$ tumors per group). Mice were dosed daily during the indicated treatment periods. ${ }^{*} P=0.027$ compared to untreated control by Mann-Whitney $U$ test. (B) Comparison of tumor volumes at 21 days after tumor implantation. 


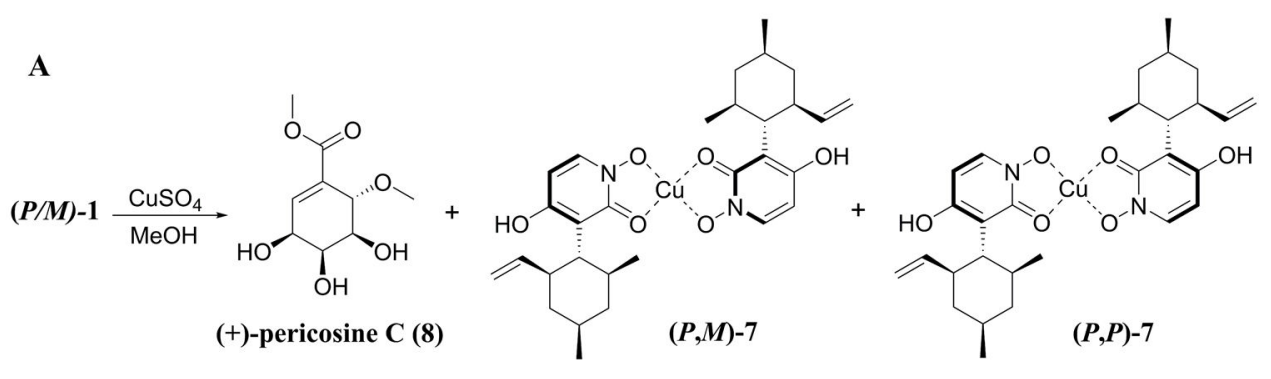

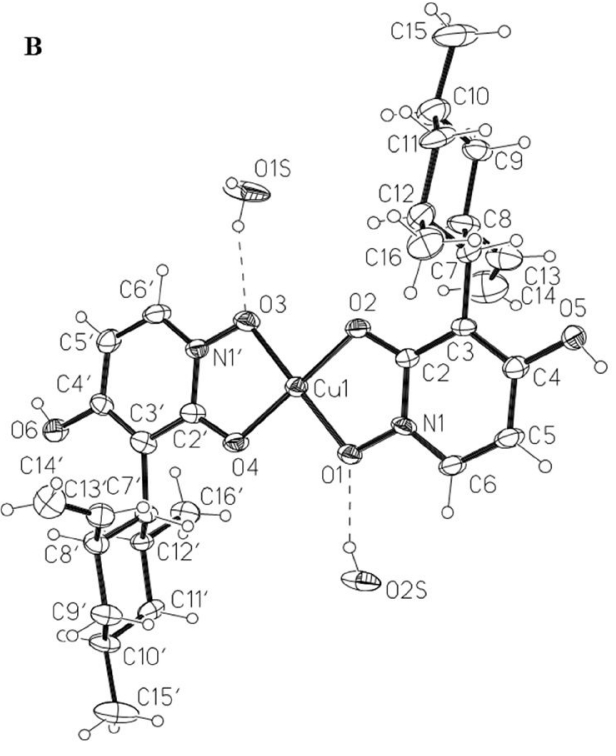

$(P, M)-7$

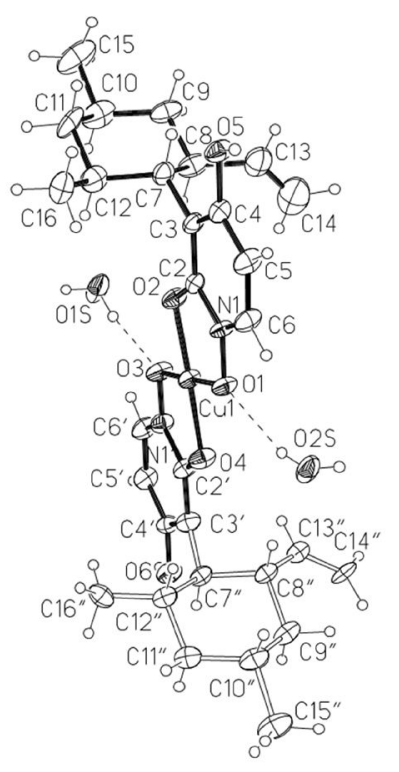

(P,P)-7

Scheme 1.

(A) $\mathrm{O}=\mathrm{C}-\mathrm{N}-\mathrm{O}-\mathrm{C}$ bridge cleavage reaction of $(\boldsymbol{P} / \boldsymbol{M}) \mathbf{- 1}$ with $\mathrm{CuSO}_{4}$ in $\mathrm{MeOH}$ and (B) ORTEP structures generated from the X-ray diffraction data for a single crystal of 7 . 


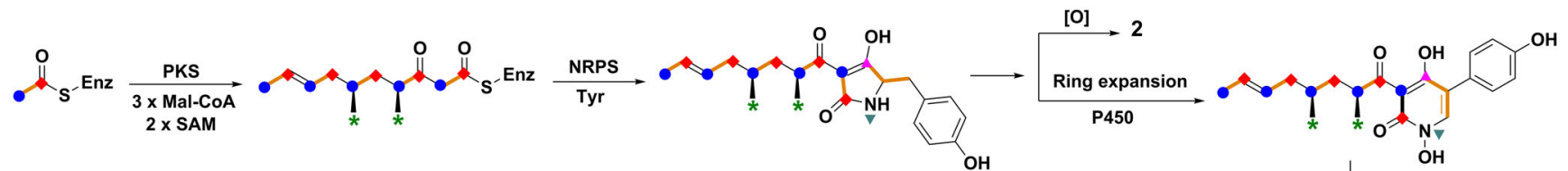

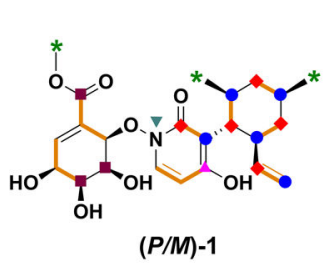
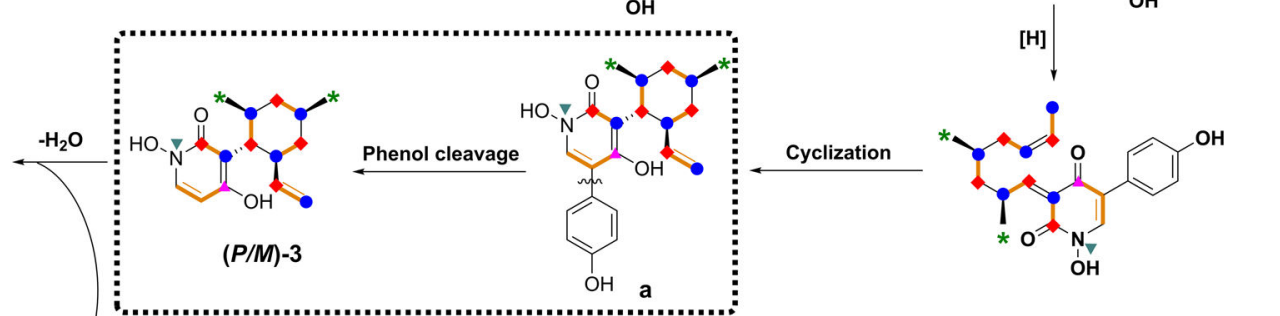

- $\left[1{ }^{13} \mathrm{C}\right]$ Sodium acetate

- $\left[2-{ }^{13} \mathrm{C}\right]$ Sodium acetate

* $\left[\mathrm{Me}^{-13} \mathrm{C}\right]-\mathrm{L}-$ Methionine

- ${ }^{15} \mathrm{~N}-\mathrm{L}-\mathrm{Ty}$ rosine

$\Delta\left[1-{ }^{13} \mathrm{C}\right]-\mathrm{L}-\mathrm{Tyr}$ rosine

- $\left[3-{ }^{13} \mathrm{C}\right]-\mathrm{D}-\mathrm{Glucose}$

- $\left[\mathrm{U}-{ }^{13} \mathrm{C}_{6}\right]-\mathrm{D}-$-Glucose

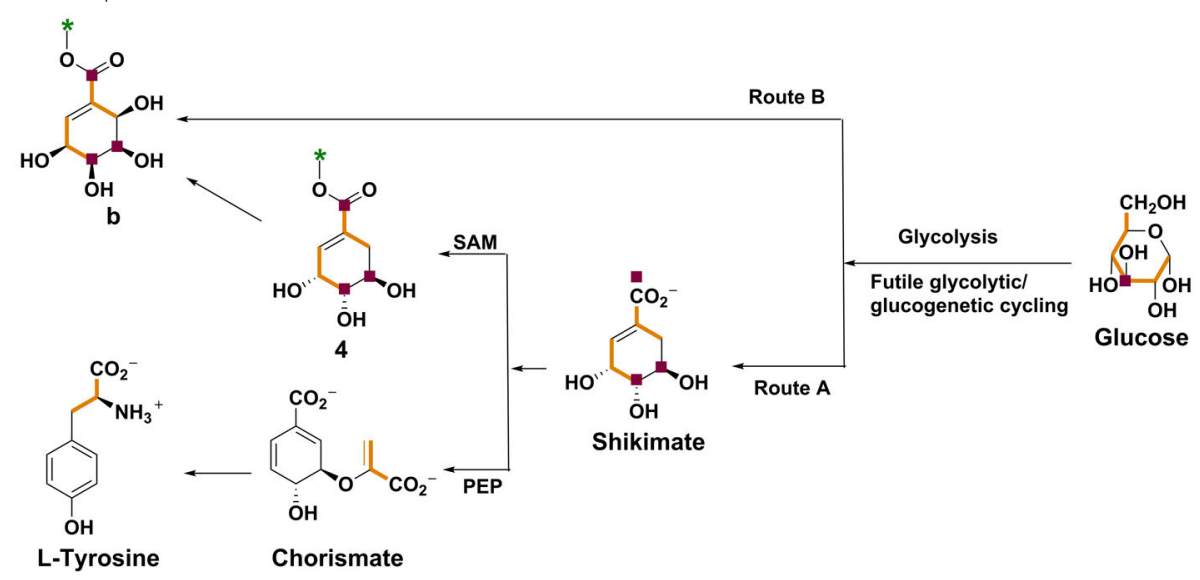

Scheme 2.

A plausible biogenetic pathway for $(\boldsymbol{P} / \boldsymbol{M}) \mathbf{- 1}$ established on the basis of stable isotope incorporation patterns for $(\boldsymbol{P} / \boldsymbol{M}) \mathbf{- 1}$ generated by feeding experiments with the Tolypocladium sp. isolate using $\left[1-{ }^{13} \mathrm{C}\right]$ sodium acetate, $\left[2-{ }^{13} \mathrm{C}\right]$ sodium acetate, $\left[\mathrm{Me}-{ }^{13} \mathrm{C}\right]-$ L-methionine, $\left[1-{ }^{13} \mathrm{C}\right]$-L-tyrosine, $\left[{ }^{15} \mathrm{~N}\right]$-L-tyrosine, $\left[3-{ }^{13} \mathrm{C}\right]-\mathrm{D}$-glucose, and [U- $\left.{ }^{13} \mathrm{C}_{6}\right]-\mathrm{D}$ glucose. 